\title{
Technological characterization of particleboards constituted with pistachio shell (Pistacia vera) and Pinus oocarpa wood
}

\author{
Flávia Maria Silva Brito ${ }^{*} \oplus$, Polyanna Xavier Souza e Silva²®, Suzane Kellen de Castro Palumbo²®, \\ José Benedito Guimarães Júnior ${ }^{2}$, Lourival Marin Mendes $^{2} \mathbb{0}$ \\ ${ }^{1}$ Universidade de São Paulo, Escola Superior de Agricultura Luiz de Queiroz, Piracicaba, SP, Brasil. E-mail: faengflorestal@gmail.com
${ }^{2}$ Universidade Federal de Lavras, Lavras, MG, Brasil. E-mail: polyannaxssilva@estudante.ufla.br; suzanekcpalumbo@estudante.ufla.br; jose.guimaraes@ufla.br; lourival@ufla.br
}

ABSTRACT: The objective of this work was to produce and characterize particleboards manufactured with pine wood and pistachio shell. Three mix proportions of 25,50 and $75 \%$ were used, and for the control, panels manufactured with $100 \%$ pistachio shell were adopted. The panels were produced with a nominal density of $0.75 \mathrm{~g} \mathrm{~cm}^{-3}$. The properties analyzed were: apparent density, water absorption, thickness swelling, modulus of rupture, modulus of elasticity and perpendicular traction. The chemical characterization of the particles showed that the extractives content of pistachio was higher than the content obtained for pine wood. There was no significant difference for physical properties and all values obtained for IE $24 \mathrm{~h}$, of panels composed of a mixture of particles (T1, T2 and T3) were contemplated by the Brazilian standard. Significant differences were found for mechanical properties, as well as a decrease in strength. The MOR of the panels made up of $25 \%$ pistachio and $75 \%$ pine wood showed a satisfactory value, as the standard requires a minimum value of $11.00 \mathrm{MPa}$ and the panels reached an average value of 11.38 $\mathrm{MPa}$. For perpendicular traction, the T1 and T2 treatment panels met the standard requirement, reaching values above $0.35 \mathrm{Mpa}$.

Key words: chemical analysis; compaction ratio; physical-mechanical properties; shell

\section{Caracterização tecnológica de painéis de partículas constituídos com casca de pistache (Pistacia vera) e madeira de Pinus oocarpa}

RESUMO: O objetivo deste trabalho foi produzir e caracterizar painéis aglomerados manufaturados com madeira de pinus e casca de pistache. Foram utilizadas três proporções de mistura de 25,50 e $75 \%$, e para o controle adotou-se painéis constituídos com $100 \%$ de casca de pistache. Os painéis foram produzidos com densidade nominal de $0,75 \mathrm{~g} \mathrm{~cm}^{-3}$. As propriedades analisadas foram: densidade aparente, absorção de água, inchamento em espessura, módulo de ruptura, módulo de elasticidade e tração perpendicular. A caracterização química das partículas evidenciou que o teor de extrativos do pistache foi superior ao teor obtido para a madeira de pinus. Não houve diferença significativa para as propriedades físicas e todos os valores obtidos para IE $24 \mathrm{~h}$, de painéis compostos por mistura de partículas (T1, T2 e T3) foram contemplados pela norma brasileira. Constataramse diferenças significativas para as propriedades mecânicas, bem como um decréscimo na resistência. O MOR dos painéis constituídos com $25 \%$ de pistache e $75 \%$ de madeira de pinus evidenciaram valor satisfatório, pois a norma exige um valor mínimo de $11.00 \mathrm{MPa}$ e os painéis atingiram valor médio de $11.38 \mathrm{MPa}$. Para tração perpendicular os painéis dos tratamentos T1 e T2 atenderam a exigência da norma, atingindo valores superiores a $0.35 \mathrm{MPa}$.

Palavras-chave: análise química; razão de compactação; propriedades físico-mecânicas; casca

\footnotetext{
* Flávia Maria Silva Brito - E-mail: faengflorestal@gmail.com (Corresponding author)

Associate Editor: Rafael Rodolfo de Melo
} 


\section{Introduction}

The particleboards are produced with wood particles impregnated with synthetic adhesives under heat and pressure (Araújo et al., 2019). For production wood from reforestation are utilized as a raw material, however the panels can be manufactured with any material containing cellulose and lignin as long as they provide satisfactory properties as dimensional stability. The quality of the final product is directly related to the type of raw material that will be used (Melo et al., 2015). Using diversified materials, associated or not, with wood can contribute in a positive direction to meet the demand of the timber sector, in addition to diversifying the sources of raw materials and adding value to alternative materials or waste.

Some experiments have already been developed with different types of alternative lignocellulosic materials and presented potential for use. Some examples stand out: Guimarães Júnior et al. (2016) evaluated eucalyptus and sorghum bagasse panels; Machado et al. (2017) conducted an experiment with babassu coconut wastes; Bazzetto et al. (2019) and Brito \& Bortoletto Júnior (2020), used bamboo particles and cane bagasse, among others.

An interesting option of alternative material, which is understudied is the pistachio. Worldwide pistachio production increased from 425 thousand tons in 2004 to 735 thousand tons in 2016 and is mainly concentrated in Iran, the United States and Turkey, which together account for over $90 \%$ of world production (Martins et al., 2019). The pistachio tree (Pistacia vera L.) is part of the Anacardiaceae famil. The tree is considered to be of moderate size ( 3 to $8 \mathrm{~m}$ ). The plants have a long youthful period and need 5 years of cultivation to reach a good crown. In Brazil, for the production of pistachios, one can take into account the use of the lines between crops intercropped with other profitable crops that can produce faster (Pommer et al., 2006).

The pistachio shells a waste from agriculture that has a considerable amount of cellulose (Kasiri \& Fathi, 2018) and has few known applications, being considered an agroindustrial waste. It has cellulose nanocrystals (CNCs), widely known for having good mechanical properties, which have proved efficient in many nanocomposites based on different polymers (Marett et al., 2017). There are few scientific works available in the literature that used pistachio as a raw material for the production of particleboards. Rare examples are: Nazerian et al. (2011) who investigated the effects of particle size of Athel, Almond and Pistachio pruning wood chips used in surface layers of panels and Alsaadi et al. (2018), who evaluated the effect of pistachio shell particles content on the mechanical properties of polyester matrix composites.

Considering the need to contribute with scientific information regarding the use of pistachio shell to produce particleboards, the objective of this work was to produce and characterize panels made up of pine and pistachio shellparticles.

\section{Materials and Methods}

\section{Particles}

The experiment was carried out at the Unidade Experimental de Painéis de Madeira [Experimental Unit of Wood Panels] - UEPAM of the Universidade Federal de Lavras [Federal University of Lavras] (UFLA). The pistachio shell was purchased in trade centers in same city.

For the production of the panels, pine logs aged 18 years old, from experimental plantings at UFLA, located in the city of Lavras, southern region of the state of Minas Gerais, were used. The trees had a length of $6.00 \mathrm{~m}$ and a diameter ranging from 20 to $30 \mathrm{~cm}$, were felled, and cut into logs of $2.00 \mathrm{~m}$ and transported to the laboratory. Approximately $9.00 \mathrm{~kg}$ of pistachio shells were used to produce the panels. The shells were stored in plastic packaging and then sealed. The material was well mixed and those with similar characteristics, free from stresses of deterioration and / or heterogeneity were selected.

The pine logs were manually debarked and made into particles, a chipper was used, and a Willey-type mil with a 4 $\mathrm{mm}$-opening meshsieve. The same mill was used to transform pistachio shells into particles. The particle sizes were 0.50 and $0.85 \mathrm{~mm}$, which were the ones with the most suitable morphology to produce the panels. Subsequently, the particles were dried in an oven maintained at $70^{\circ} \mathrm{C}$ until they reach $3 \%$ humidity and packed in sealed plastic bags for later use.

\section{Basic density and chemical characterization of particles}

The basic density, being determined according to the Brazilian Standard NBR 11941 (ABNT, 2003a). Samples of pine and pistachio particles were collected, which were transformed into sawdust in a Willey type mill. The sawdust obtained was classified and the material with a 60 mesh grain size was selected. For the analysis of lignin, the recommendations of NBR 7989 (ABNT, 2010a) were followed. To determine the extractives, the procedures of NBR 14853 (ABNT, 2010b) were followed. The ashes were obtained according to NBR 13999 (ABNT, 2003b). The percentage of holocellulose was determined by adding the levels of extractives and lignins, subtracted from 100, as shown in Equation 1.

$$
\text { Holocellulose content }(\%)=100-(\mathrm{TE}+\mathrm{RL}+\mathrm{SL})
$$

where:

TE - total extractives;

$\mathrm{RL}$ - residual lignin; and,

$\mathrm{SL} \quad$ - soluble lignin.

\section{Panel production process}

The pre-established nominal density for the panels was 0.75 $\mathrm{g} \mathrm{cm}^{-3}$. The adhesive used was urea-formaldehyde (UF) in the proportion of $12 \%$ solids based on the dry mass of the particles. The characteristics of the adhesive were: solids content of $62 \%$, viscosity of $380 \mathrm{cP}$, pH of 8.5 , gel time of $2.5 \mathrm{~min}$, as specified by the technical sheet accompanying the product. 
The particles were dried at $3 \%$ dry basis humidity, glued with the adhesive, and distributed in a wooden box $(30 \times 30$ $\times 10 \mathrm{~cm}$ ) to form the mattress. Then the mattress was taken to a hydraulic press for pre-consolidation. The mattress was hot pressed ( $4 \mathrm{MPa}$ of pressure, temperature of $160^{\circ} \mathrm{C}$, for 8 $\mathrm{min})$. The final dimensions of the panels were $30 \times 30 \times 1.5 \mathrm{~cm}$ (length $\times$ width $\times$ thickness, respectively). The panels obtained were arranged in an upright position until they reached room temperature. The panels were air-conditioned (temperature of $22 \pm 2 \stackrel{\circ}{\circ}$ and relative humidity of $65 \pm 5 \%$ ) and square cut for sample removal, according to the Brazilian Standard NBR 14810-3 (ABNT, 2013a).

\section{Experimental design and analysis of results}

For the analysis of the chemical components of the particles, descriptive statistics were used, with mean values and the respective standard deviations. The compaction ratio was calculated by the ratio between the density of the panel and the density of the lignocellulosic material. The density of the material was calculated by multiplying the percentage used of each material by its respective density.

The nominal density adopted was $0.75 \mathrm{~g} \mathrm{~cm}^{-3}$. A completely randomized design (DIC) was used, with 3 replicates per treatment, thus totaling 12 experimental units. The experiment consisted of four treatments based on the composition of mixtures of pine and pistachio particles to manufacture the panels, being: $\mathrm{T} 1=25 \%$ pistachio $+75 \%$ pine; $\mathrm{T} 2=50 \%$ pistachio $+50 \%$ pine; $\mathrm{T} 3=75 \%$ pistachio $+25 \%$ pine and $\mathrm{T} 4=100 \%$ pistachio.

The properties evaluated were density, water absorption, thickness swelling, static bending (modulus of elasticity and modulus of rupture) and perpendicular traction. To assess water absorption and thickness swelling, after 2 and $24 \mathrm{~h}$ of immersion, static bending, and perpendicular traction, four specimens per panel were removed for each test.

Lilliefors and Cochran tests checked the normality of the data and homogeneity of the variances, respectively. The results were analyzed with analysis of variance and linear regression at $5 \%$ significance for physical properties. For mechanical properties, analysis of variance and the ScottKnott test were used, both with $5 \%$ significance. Additionally, the mean values of the physical and mechanical properties of the panels were compared with the parameters required by NBR 14810-3 (ABNT, 2013a), which stipulate the requirements for non-structural panels for indoor use in dry conditions (Type P2).

\section{Results and Discussion}

\section{Basic density and chemical characterization of particles}

The density basic observed for pistachio was $0.88 \mathrm{~g} \mathrm{~cm}^{-3}$ and for pinewood an mean value of $0.55 \mathrm{~g} \mathrm{~cm}^{-3}$ was obtained. Pinewood can be considered as medium density, since its values are in the range between 0.55 and $0.75 \mathrm{~g} \mathrm{~cm}^{-3}$ and pistachio can be considered as a high-density material, since its value is above $0.75 \mathrm{~g} \mathrm{~cm}^{-3}$ (IPT, 1989).
Table 1. Mean values of the contents of total extractives, lignin, holocellulose and ash from pine particles and pistachio shell.

\begin{tabular}{crccc}
\hline \multirow{2}{*}{$\begin{array}{c}\text { Treatments } \\
\text { (Particles) }\end{array}$} & Extractives & Lignine & Holocellulose & Ashes \\
\cline { 2 - 5 } & \multicolumn{4}{c}{$(\%)$} \\
\hline Pistachio & $21.94(2.28)$ & $24.74(4.62)$ & $51.51(7.00)$ & $1.80(0.09)$ \\
Pine & $6.34(0.28)$ & $29.43(0.73)$ & $63.29(1.05)$ & $0.93(0.03)$ \\
\hline
\end{tabular}

* Mean values in parentheses represent the standard deviation.

The mean values shown in Table 1, refer to the extractive, lignin and holocellulose contents of the analyzed materials.

According to the values described in Table 1 , it is observed that the average extractive content obtained for the pistachio particles, was higher than the content obtained for the pine particles. Alsaadi et al. (2018) reported a lower value than that obtained in this study, corresponding to $0.18 \%$ of extractives for pistachio shells. The content of extractives obtained for pistachio, indicates that the type of particle coming from this material, can trigger unsatisfactory results in the process of gluing the panels.

The average content obtained for Pine is like that reported by Matos et al. (2019), who worked with the same species and obtained $6.33 \%$. On the other hand, Teodoro et al. (2015) analyzed the chemical constituents of Pinus oocarpa and found an average content of $5.20 \%$, lower than that obtained in this study. The difference between the results may be due to factors such as methodologies adopted in the extraction process, types of solvents, species used, age and environmental factors. Of the chemical constitutions of wood, the content of extractives is one of the important parameters to effect a good bonding (Santiago et al., 2018), since if found in high levels they can contribute negatively in the cure and polymerization of the adhesive.

Also, according to Table 1 , it is observed that the average lignin content obtained for pistachio was lower than pine. Alsaadi et al. (2018) obtained a content of $13.50 \%$ of lignin for pistachio shells, lower than that obtained in this study. The mean value obtained by Teodoro et al. (2015) for pine wood was lower $(28.30 \%)$, as reported in the present study. Matos et al. (2019) obtained a value like that reported in this study of $29.97 \%$. Higher levels of lignin are desirable in the composition of the material used in the manufacture of particleboards, as this component has a very condensed structure and an irregular aspect that gives the material high rigidity (Sweet \&Winandy, 1999).

Regarding the holocellulose fraction (Table 1), the mean value obtained for pistachios was lower than the value obtained for pine. Alsaadi et al. (2018) mentioned that the value obtained only for the cellulose fraction was $42.00 \%$, however due to the mass balance, of the macromolecular elements, available in the manuscript, it is considered that $81.95 \%$ is the value obtained for the holocellulose content of the pistachio shells, thus being higher than the value obtained in this experiment. The reports in the literature for the lignin content of pine wood were higher. Teodoro et al. (2015) found an mean value of $66.20 \%$ and Matos et al. (2019) obtained a mean value of $66.54 \%$. 
Regarding the ash content, an mean value of was obtained for pistachios, practically double the value obtained for pine. Alsaadi et al. (2018) obtained a higher value for ash content $(1.26 \%)$. The values reported in the literature, for the ash content of pine wood were lower than the results obtained in this study. Teodoro et al. (2015) obtained an mean value of $0.40 \%$ and Matos et al. (2019) found an average content of $0.15 \%$. The ash content is directly related to the varieties of the material, type of fertilization, cultivation conditions, place of growth and age, factors that can explain the differences obtained in each experiment.

In general, the differences observed between the values obtained in the present study and the values in the literature for chemical composition, especially in relation to pistachio shell be explained due to some factors, such as utilized solvent, extraction method, extraction time, species, age of the material used and environmental factors.

\section{Physical properties of the particleboards}

It can be seen in Table 2 that as the pistachio particles were added, the compaction ratio values (nominal and effective) were being reduced. It is observed that, as the pistachio particles were added, the compaction ratio values (nominal and effective) were being reduced. All values are below the range considered ideal from 1.3 to 1.6 (Maloney, 1993). Values within this range would be adequate to obtain good densification and quality of the panels. Higher values of the compaction ratio promote improvements in resistance to bending and perpendicular traction, due to the better contact between the particles. The disadvantage would be a negative influence on the physical properties of absorption and swelling (Maloney, 1993).

Regarding the apparent density (Table 2), it is observed that there was no significant effect of the addition of pistachio on the apparent density of the panels. The panels of all treatments are medium density, according to NBR 14810-3 (ABNT, 2013a). The importance of this classification is directly related to the minimum values of swelling in thickness, water absorption, modulus of elasticity, modulus of rupture and perpendicular traction (Machado et al., 2017).

Table 2. Mean values of nominal compaction ratio (RCN) and effective compaction ratio (RCE) apparent density of the panels.

\begin{tabular}{cccc}
\hline $\begin{array}{c}\text { Treatments } \\
\text { (compositions) }\end{array}$ & RCN & RCE & $\begin{array}{c}\text { Basic density } \\
\left(\mathrm{g} \mathrm{cm}^{-3}\right)\end{array}$ \\
\hline T1 - 25\% pistachio + 75\% pine & 1.25 & 1.15 & $0.73(0.01)$ \\
T2 - 50\% pistachio + 50\% pine & 1.10 & 1.02 & $0.73(0.06)$ \\
\hline T3 - 75\% pistachio + 25\% pine & 0.99 & 0.94 & $0.75(0.08)$ \\
\hline T4 - 100\% pistachio & 0.90 & 0.85 & $0.75(0.04)$ \\
\hline
\end{tabular}

The values obtained for density were different from the nominal density value for the treatments T1 and T2. This fact is common in laboratory experiments and may be associated with the loss of inputs (adhesive and paraffin), at the time of sprinkling and eventual loss of particles, during the manual production phase of the mattress, as well as during prepressing, hot pressing, and packaging, in which the volume of the panels may increase and, thus, reduce the nominal density (Guimarães Júnior et al., 2016; Bazzetto et al., 2019). Other researchers, who worked with panels, also reported this occurrence while conducting the experiments (Teodoro et al., 2015; Guimarães Júnior et al., 2016; Brito \& Bortoletto Júnior, 2020).

The mean values obtained for water absorption after $2 \mathrm{~h}$ (WA 2h) and $24 \mathrm{~h}$ (WA $24 \mathrm{~h}$ ) and thickness swelling, after $2 \mathrm{~h}$ (TS $2 \mathrm{~h}$ ) and $24 \mathrm{~h}$ (TS $24 \mathrm{~h}$ ), are described in Table 3 . The results show that there is no significant effect on the percentages of pistachios associated with pine wood.

According to Table 3, it is observed that the mean values for WA $2 \mathrm{~h}$ varied between 33.96 to $72.21 \%$. For WA $24 \mathrm{~h}$ the values varied between 61.15 and $95.39 \%$. It is noted that the insertion of particles of material of higher density (pistachio), caused a tendency of increase in the water absorption rates. According to Maloney (1993) the greater compaction of particleboards makes it difficult and reduces the entry of water into the inner layers of the panel, reducing the amount of water absorption.

It is assumed that the panels manufactured with greater amounts of pine, had a more compact arrangement, due to the need for greater amounts of particles to form the mattress, as they are less dense. As pistachio particles (denser) were added, the mattress was less compacted, that is, a smaller volume of particles was necessary, resulting in an increase in empty spaces, which facilitated the entry of water into the panel.

A similar trend was observed by Melo et al. (2015), who conducted an experiment with panels made of different densities materials. The researchers evaluated the influence of the addition of bamboo particles on the physical-mechanical properties of the particleboards by means of regression analysis. Two species were used, being Eucalyptus grandis, with density of $0.51 \mathrm{~g} \mathrm{~cm}^{-3}$ and Bambusa vulgaris, with density of $0.63 \mathrm{~g} \mathrm{~cm}^{-3}$. The panels were produced using the urea-formaldehyde adhesive with the addition of $0,25,50,75$ and $100 \%$ bamboo. The nominal density was $0.70 \mathrm{~g} \mathrm{~cm}^{-3}$. The adhesive used was urea-formaldehyde, in the proportion of $8 \%$ solids based on the dry mass of the particles. $1 \%$ paraffin in liquid form was added. The final pressing was carried out in

Table 3. Mean values of water absorption (WA $2 \mathrm{~h}$ and WA $24 \mathrm{~h}$ ) and thickness swelling (TS $2 \mathrm{~h}$ and TS $24 \mathrm{~h}$ ) of the panels.

\begin{tabular}{|c|c|c|c|c|}
\hline Treatments & WA $2 \mathrm{~h}$ & WA $24 \mathrm{~h}$ & TS $2 \mathrm{~h}$ & TS $24 \mathrm{~h}$ \\
\hline T1 - 25\% pist. + 75\% pine & 33.96 a (3.50) & 61.15 a $(0.65)$ & $11.04 \mathrm{a}(1.01)$ & $14.79 \mathrm{a}(1.20)$ \\
\hline $\mathrm{T} 2-50 \%$ pist. $+50 \%$ pine & 56.93 a $(5.00)$ & 69.22 a (4.00) & 11.04 a $(1.00)$ & 17.33 a (1.10) \\
\hline T3 $-75 \%$ pist. $+25 \%$ pine & 57.53 a (2.20) & 70.64 a (3.40) & 12.07 a $(0.80)$ & 17.44 a $(0.90)$ \\
\hline
\end{tabular}

Means followed by the same letter in the column do not differ (Tukey; $p>0.05$ ); Values in parentheses are the standard deviation. 
a hydraulic press, with a temperature of $180{ }^{\circ} \mathrm{C}$ and a pressure of 3.0 MPa during nine min of pressing.

For WA $2 \mathrm{~h}$ and WA $24 \mathrm{~h}$ obtained mean values in a range between 5.0 to $30 \%$ and 30 to $90 \%$, respectively, being lower than those obtained in this study. It should be noted that paraffin emulsion was used, which aims to reduce the hygroscopic rate of the particles and improve the stability of the panels. The addition of particles of the higher density material (bamboo), resulted in higher water absorption rates (Melo et al., 2015).

On the other hand, a contrary trend was reported by Teodoro et al. (2015), who worked with layered panels composed of different compositions using bamboo, with basic density of $0.50 \mathrm{~g} \mathrm{~cm}^{-3}$ and pine with basic density equivalent to $0.26 \mathrm{~g} \mathrm{~cm}^{-3}$. The treatments were based on increasing amounts of bamboo, so that the compaction ratio increased with the addition of the particles of the higher density material. The percentage distribution corresponded to 20:60:20 (face/ core/face) The nominal density of the panels was $0.70 \mathrm{~g} \mathrm{~cm}$ 3. UF-based adhesive was used. For pre-pressing, a pressure equivalent to 0.4 MPa was used. The pressing cycle parameters were: $4 \mathrm{MPa}$, temperature of $160{ }^{\circ} \mathrm{C}$ for $8 \mathrm{~min}$. They used regression analysis to evaluate the properties.

For WA $2 \mathrm{~h}$ and WA $24 \mathrm{~h}$ the values obtained were in a range between 60 to $90 \%$ and 75 to $105 \%$, respectively, being higher than those obtained in this study. It should be noted that paraffin was not used to manufacture of the panels. A decrease was observed in water absorption values, with an increase in bamboo particles in the center of the panels. This has been justified by addition of bamboo particles improved the properties and explained the result based on the gradual increase in the rate of compaction, which occurs as the proportion of bamboo particles increases and gradually decreases the porosity of the panel.

For TS $2 \mathrm{~h}$, the mean values observed ranged from 11.04 to $13.00 \%$, while for TS $24 \mathrm{~h}$, the values were 14.78 and $22.57 \%$ (Table 3). The results obtained for the TS $2 \mathrm{~h}$ were equivalent for the percentages of 25 and $50 \%$ of pistachio particles, reaching the same value. As previously mentioned, as the percentage of pistachio particles is added to the composition of the panels, there is also an increase in the thickness swelling rates, for both immersion times.

A similar trend was observed by Melo et al. (2015), that obtained values within a range between 5 and $17 \%$ and 20 and $40 \%$, for the properties of TS $2 \mathrm{~h}$ and TS $24 \mathrm{~h}$, respectively. The values were higher than those reported in this study. The inclusion of bamboo particles in the panels caused a loss of stability after two hours of immersion in water, but after 24 $\mathrm{h}$ there was no tendency to increase or decrease stability, with the increase of bamboo particles in the panels. Melo et al. (2015) stated that, although the panels with higher proportions of bamboo have shown a greater absorption of water, for thickness swelling, a greater release of the compression stresses provided by the lower specific mass of the bamboo particles, may have influenced the achievement of this result.
Teodoro et al. (2015) obtained mean values for TS $2 \mathrm{~h}$ and TS $24 \mathrm{~h}$, between 14 and $20 \%$ and 16 and $245 \%$, respectively, being higher than those obtained in this study. Observed a significant reduction in the values, as bamboo particles were added to the composition of the panels. NBR 14810-3 (ABNT, 2013) does not stipulate values for TS $2 \mathrm{~h}$, only for TS $24 \mathrm{~h}$ and allows a maximum percentage of $18 \%$. In this way, the panels produced with compositions of the mix of the pine with pistachio (T1, T2 and T3) met the recommendations of the standard, so they are adequate are suitable for use in places of internal use in dry conditions.

\section{Mechanical properties of the particleboards}

Figure 1 shows the regression analysis between the modulus of rupture data and the percentage insertion of pistachio particles in the composition of the panels. Linear regression shows that approximately $92 \%$ of the modulus of rupture variation can be explained by the insertion of pistachio particles in the composition of the panels. The regression between MOR and the pistachio percentage had a coefficient of determination of 0.9194 and the correlation was significant at the $5 \%$ probability level. For each unit of (\%) pistachio inserted in the composition of the panels, there was a reduction equivalent to $0.0236 \mathrm{MPa}$ in the rupture module panels.

Figure 2 shows the regression analysis between the data on the modulus of elasticity and the percentage of pistachio particles. The linear regression shows that $81 \%$ of the MOE variation can be explained by the insertion of pistachio particles in the composition of the panels. The regression between the MOE and the pistachio percentage had a coefficient of determination of 0.8124 and the correlation was significant at the level of $5 \%$ probability. The MOE showed a behavior similar to MOR, since it was reduced with the increase in the percentage of pistachio particles in the composition of the

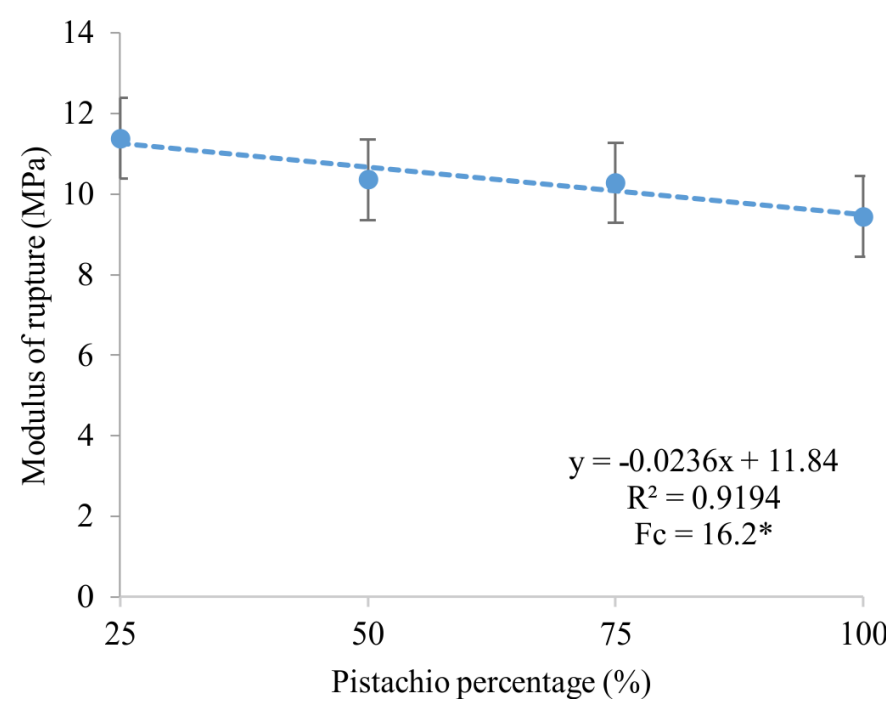

The regression was significant at the $5 \%$ level of significance. $R^{2}=0.92 ; \mathrm{Fc}=16.2^{*}$

Figure 1. Linear regression analysis for the modulus of rupture as a function of the pistachio percentage in the composition of the panels. 


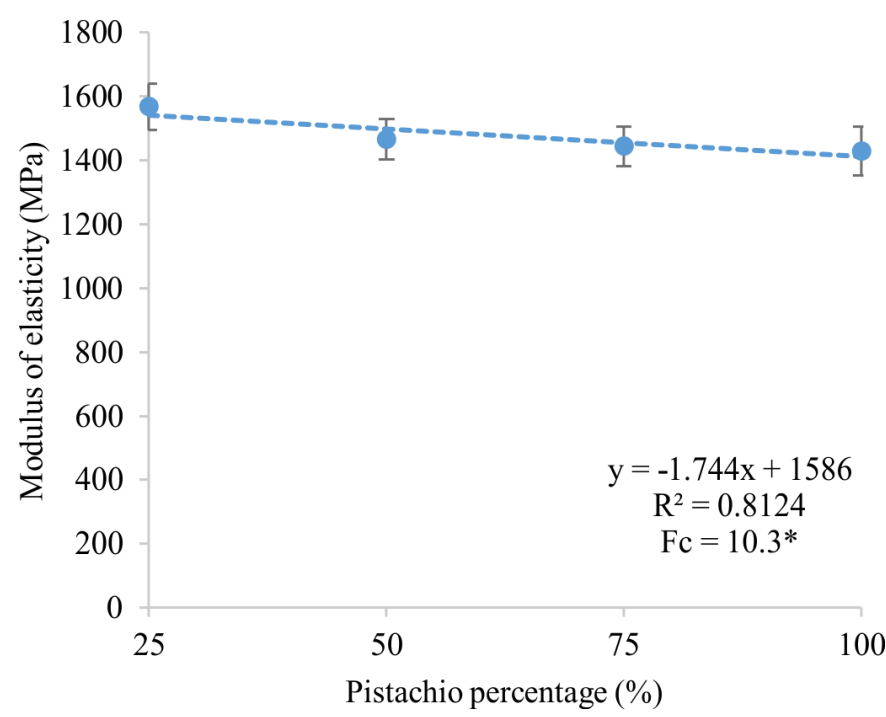

The regression was significant at the $5 \%$ level of significance. $R^{2}=0.81 ; F c=10.3^{*}$

Figure 2. Linear regression analysis for the modulus of elasticity, as a function of the pistachio percentage in the composition of the panels.

panels. For each unit of $\%$ pistachio inserted in the composition of the panels, there was a reduction equivalent to $1.744 \mathrm{MPa}$ in the MOE of the panels.

All the equations presented showed a high coefficient of determination, indicating that the addition of pistachio particles caused a reduction in resistance. The mean values obtained for MOR and MOE, can be explained by the low compaction ratio, which was reduced as the pistachio was added. The contact area between particles, being relatively low, can increase the availability of adhesive, but, on the other hand, has a smaller number of adhesive bonds between particles. Thus, the increase in empty spaces, results in panels that are less homogeneous and less resistant to the distribution of efforts applied in the tests.

This statement corroborates observations made by Brito \& Bortoletto Júnior (2020) when working with panels made up of particles of denser material, in this case bamboo. The particles were glued with $10 \%$ UF-based adhesive, nominal density of $0.65 \mathrm{~g} \mathrm{~cm}^{-3}$ and thickness of $15.70 \mathrm{~mm}$. Obtained low values of MOR (6.38 to $7.54 \mathrm{MPa}$ ) and MOE (553.77 to $630.40 \mathrm{MPa}$ ) and attributed the results to the relatively low compaction rate caused by the bamboo particles. Brito \& Bortoletto Júnior (2020) cited that a relatively small contact area between the particles can increase the relative availability of the adhesive, however, it causes a lesser amount of adhesive bond between the particles.

The same trend has been reported by some researchers in the literature. Bianche et al. (2012) evaluated panel properties with materials of different densities, including Eucalyptus urophylla $\left(0.56 \mathrm{~g} \mathrm{~cm}^{-3}\right)$ and Schizolobium amazonicum (0.26 $\left.\mathrm{g} \mathrm{cm}^{-3}\right)$. Panels were produced with mixtures in 4 proportions $(25,50,75$ and $100 \%)$ of particles glued with UF-based adhesive. Observed the same downward trend in the values of MOR and MOE when adding particles of greater density to the composition of the panels. The values obtained ranged from
10.88 to $26.44 \mathrm{MPa}$ and for the MOE, the values were from 1383.81 to $2955.69 \mathrm{MPa}$, being higher than those obtained in this study.

Melo et al. (2015) observed the same trend when adding bamboo particles to the composition of the panels. The results obtained indicated reductions in the strength and stiffness of the panels with the percentage increase of the bamboo particles, which is the densest material. Teodoro et al. (2015) did not observe significant differences between the values found. For MOR values were reached between 13.9 to $17.40 \mathrm{MPa}$. For the $\mathrm{MOE}$, the values obtained were in a range from 1636.0 to $2077.0 \mathrm{MPa}$.

The panels made with $25 \%$ pistachio $+75 \%$ pine reached a mean value of $11.38 \mathrm{MPa}$ for the MOR (Figure 1), this result being higher than that stipulated by NBR 14810-2 (ABNT, 2013b), which establishes the minimum value of 11.0 $\mathrm{MPa}$. For the MOE, the panels reached a higher mean value corresponding to $1,568 \mathrm{MPa}$ (Figure 2), this value is below the minimum limit acceptable by NBR 14810-3 (ABNT, 2013) which establishes values above $1,600 \mathrm{MPa}$. In general, it can be said that the T4 treatment panels (25\% pistachio $+75 \%$ pine) showed a difference of $2.0 \%$ below average, so the panels were the closest to the minimum value stipulated by NBR 14810-3 (ABNT, 2013a). It should also be noted that the T2 (75\% pistachio $+25 \%$ pine) and T3 (50\% pistachio $+50 \%$ pine) treatment panels reached values with a small difference of 5.82 and $6.55 \%$, respectively, to reach the minimum value stipulated by the standard.

Figure 3 represents the regression analysis between the data of perpendicular traction (PT) and the percentage of pistachio particles. The regression between perpendicular traction (PT) and the pistachio percentage had a coefficient of determination of 0.9412 and the correlation was significant

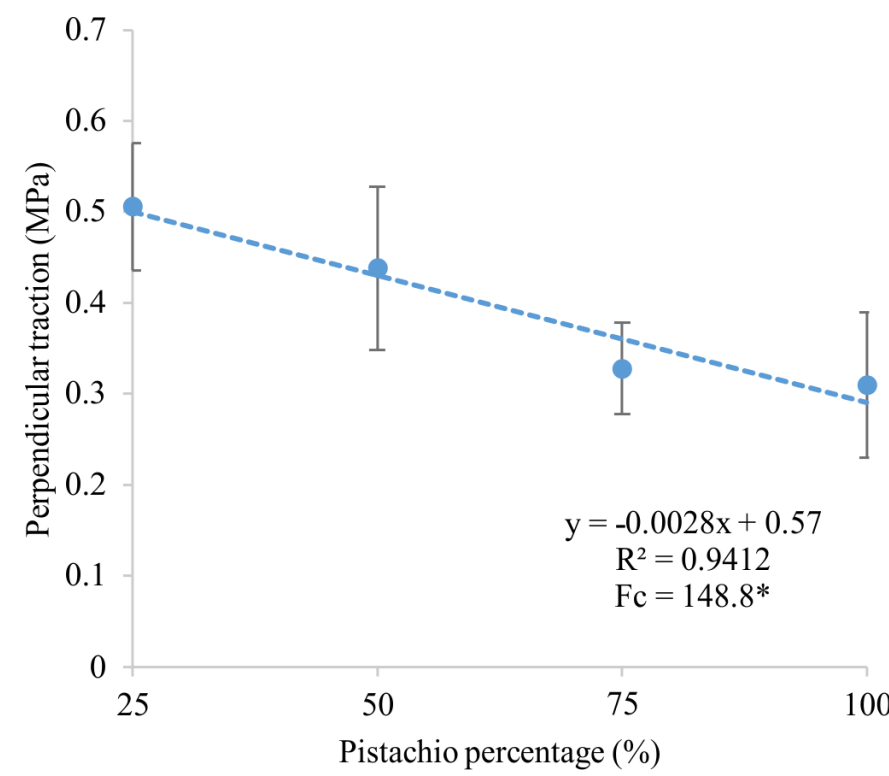

The regression was significant at the $5 \%$ level of significance. $R^{2}=0.94 ; F c=148.8^{*}$

Figure 3. Linear regression analysis for the perpendicular traction as a function of the pistachio percentage in the composition of the panels. 
at the level of $5 \%$ probability, confirmed by the value of $F$ calculated in the regression analysis.

PT showed the same behavior as the rupture and elasticity modulus, since the values were reduced, as pistachio particles were added to the composition of the panels and $94 \%$ of the variation of these properties can be explained by the addition of the pistachio particles (Figure 3). For each unit of (\%) pistachio there was a reduction equivalent to $0.0028 \mathrm{MPa}$ in the PT of the panels.

A possible cause, which could explain the result obtained, would be the geometry of the pistachio particles and their density, since particles of shorter length show a smaller surface area of contact. While materials of higher density, such as pistachio, make it difficult to compact the particles in the mattress, causing greater amounts of empty spaces, less adhesion between the particles and, consequently, reducing the bonding quality. These facts were observed and confirmed in research carried out by Brito et al. (2020) when working with particleboards using two materials of different densities (bamboo and sugarcane bagasse).

It should also be noted that the chemical analysis of the particles showed a high value of extractives and ashes in the pistachio (Table 1), which may have impaired the process of bonding the particles, since the values of PT were reduced, as the pistachio particles were added. As previously mentioned, the content of extractives can negatively influence the curing and polymerization of the adhesive.

Bianche et al. (2012) reported values higher than those obtained in this study for perpendicular traction strength. Obtained results between 0.38 and $0.75 \mathrm{MPa}$. Teodoro et al. (2015) found no significant differences between treatments and obtained mean values between 0.66 and $0.81 \mathrm{MPa}$. The NBR 14810-3 (ABNT, 2013a), stipulates a minimum value of $0.35 \mathrm{MPa}$, as a limit, so the panels of treatments T3 and T4, presented satisfactory behavior in relation to $\mathrm{TP}$, since they obtained values of 0.44 and $0.51 \mathrm{MPa}$.

\section{Conclusions}

Regarding the chemical composition, the extractives content of pistachios was higher than triple the content obtained for pine, as well as the amount of ash, which was practically double the amount obtained for pine.

There was a tendency to increase physical properties with the insertion of pistachio particles in the composition of the particleboards, however the mean values of TS $24 \mathrm{~h}$ for the treatments T1, T2 and T3 contemplated the minimum requirement stipulated by Brazilian standard.

For MOR, composite panels with $75 \%$ pistachio particles and $25 \%$ pine particles reached the minimum value required by Brazilian standard. The MOE indicated low resistance potential and did not meet the minimum value required by the standard. For perpendicular traction, panels made up of 25 and $50 \%$ pistachio particles showed satisfactory value, according to the standard used.

\section{Compliance with Ethical Standards}

Funding: FAPEMIG (Fundação de Amparo à Pesquisa do Estado de Minas Gerais) and CNPq (Conselho Nacional de Desenvolvimento Científico e Tecnológico).

Conflict of interest: The authors declare that there is no conflict of interest (professional or financial) that can influence the publication of the article.

Author contributions: Conceptualization: JBGJ; Data Curation: PXSS, SKCP, JBGJ; Formal analysis: JBGJ; Funding acquisition: JBGJ; Investigation: PXSS, SKCP; Methodology: PXSS, SKCP; Project administration: JBGJ, LMM; Resources: JBGJ, LMM; Supervision: JBGJ; Validation: FMSB; Visualization: FMSB; Writing - original draft: FMSB; Writing - review \& editing: FMSB.

\section{Literature Cited}

Alsaadi, M.; Erkliğ, A.; Albu-khaleefah, K. Effect of pistachio shell particle content on the mechanical properties of polymer composite. Arabian Journal Science Engineering, v. 43, p. 46894696, 2018. https://doi.org/10.1007/s13369-018-3073-x.

Araújo, C. K. C.; Campos, C. I.; Camargo, S. K. C. A.; Camargo, B. S. Caracterização mecânica de painéis particulados de média densidade produzidos a partir de resíduos de madeira. Revista Gestão Industrial, v. 15, n. 1, p. 197-211, 2019. https://doi. org/10.3895/gi.v15n1.9159.

Associação Brasileira de Normas Técnicas - ABNT. NBR 11941: Madeira - determinação da densidade básica. Rio de Janeiro: ABNT, 2003a.

Associação Brasileira de Normas Técnicas - ABNT. NBR 13999: Determinação do resíduo (cinza) após a incineração a $525^{\circ} \mathrm{C}$. Rio de Janeiro: ABNT, 2003b.

Associação Brasileira de Normas Técnicas - ABNT. NBR 14810-2: Chapas de madeira aglomerada. Parte 2: requisitos e métodos de ensaio. Rio de Janeiro: ABNT, 2013b. 4p.

Associação Brasileira de Normas Técnicas - ABNT. NBR 14810-3: Chapas de madeira aglomerada. Parte 3: métodos de ensaio. Rio de Janeiro: ABNT, 2013a. 51p.

Associação Brasileira de Normas Técnicas - ABNT. NBR 7989: Pasta celulósica e madeira - determinação de lignina insolúvel em ácido. Rio de Janeiro: ABNT, 2010a.

Associação Brasileira de Normas Técnicas- ABNT. NBR 14853: Determinação do material solúvel em etanol-tolueno e em diclorometano e em acetona. Rio de Janeiro: ABNT, 2010b.

Bazzetto, J. T. L.; Bortoletto Junior, G.; Brito F. M. S. Effect of particle size on bamboo particle board properties. Floresta e Ambiente, v. 26, n. 2, p. 1-8, 2019. https://doi.org/10.1590/2179-8087.012517.

Bianche, J. J.; Carneiro, A. C. O.; Vital, B. R.; Pereira, F. A.; Santos, R. C.; Soratto, D. N. Propriedades de painéis aglomerados fabricados com partículas de eucalipto (Eucalyptus urophylla), paricá (Schizolobium amazonicum) e vassoura (Sida spp.). Cerne, v.18, n.4, p.623-630, 2012. https://doi.org/10.1590/S0104-77602012000400012.

Brito, F. M. S.; Bortoletto Júnior, G. Properties of particleboards manufactured from bamboo (Dendrocalamus asper). Revista Brasileira de Ciências Agrárias, v.15, n.1, p.1-10, 2020. https:// doi.org/10.5039/agraria.v15i1a7245. 
Brito, F. M. S.; Bortoletto Júnior, G.; Paes, J. B.; Belini, U. L.; TomazelloFilho, M. Technological characterization of particleboards made with sugarcane bagasse and bamboo culm particles. Construction and Building Materials, v. 262, e120501, 2020. https://doi. org/10.1016/j.conbuildmat.2020.120501.

Guimarães Júnior, J. B.; Xavier, M. M.; Santos, T. S.; Protásio, T. P.; Mendes, R. F.; Mendes. L. M. Inclusão de resíduo da cultura de sorgo em painéis aglomerados de eucalipto. Pesquisa Florestal Brasileira, v. 36, n. 88, p. 435-442, 2016. https://doi. org/10.4336/2016.pfb.36.88.1036.

Instituto de Pesquisas Tecnológicas - IPT. Fichas de características das madeiras brasileiras. 2. ed. São Paulo: IPT, 1989. 418 p.

Kasiri, N.; Fathi, M. Production of cellulose nanocrystals from pistachio shells and their application for stabilizing pickering emulsions. International Journal of Biological Macromolecules, v.106, p. 1023-1031, 2018. https://doi.org/10.1016/j. ijbiomac.2017.08.112.

Machado, N. A. F.; Furtado, M. B.; Parra-Serrano, L. J.; Parente, M. O. M.; Fiorelli, J.; Savastano Júnior, H. Painéis aglomerados fabricados com resíduos do coco babaçu. Revista Brasileira de Ciências Agrárias, v.12, n.2, p. 202-209, 2017. https://doi. org/10.5039/agraria.v.12i2a5434.

Maloney, T. M. Modern particleboard e dry-process fiberboard manufacturing. 2.ed. São Francisco: Miller Freeman Publication, 1993. $689 \mathrm{p}$.

Marett, J.; Aning, A.; Foster, E. J. The isolation of cellulose nanocrystals from pistachio shells via acid hydrolysis. Industrial Crops and Products, v. 109, p. 869 - 874, 2017. https://doi.org/10.1016/j. indcrop.2017.09.039.

Martins, C. R.; Marco, R.; Farias, R. M.; Malgarin, M. B. Noz-pecã Panorama Mundial. Campo \& Negócios, Hortifruti, p. 52-55, 2019. (Informe Técnico). https://ainfo.cnptia.embrapa.br/digital/ bitstream/item/204510/1/Noz-peca-Panorama-Mundial.pdf. 28 Jul. 2020.
Matos, A. C.; Guimarães Júnior, J. B.; Borges, C. C.; Matos, L. C.; Ferreira, J. C.; Mendes, L. M. Influência de diferentes composições de lâminas de Schizolobiumparahybavar. amazonicum (Huber exnDucke) Barneby e Pinus oocarpa var. oocarpa (Schiede ex Schltdl) para produção de compensados multilaminados. Scientia Forestalis, v. 47, n. 124, p. 799-810, 2019. https://doi. org/10.18671/scifor.v47n124.21.

Melo, R.R.; Stangerlin, D. M.; Santana, R. R. C.; Pedrosa, T. D. Decay and Termite Resistance of Particleboard Manufactured from Wood, Bamboo and Rice Husk. Maderas. Ciencia y Tecnología, v. 17, n. 1, p. 55-62, 2015. https://doi.org/10.4067/S0718-221X2015005000006.

Nazerian, M.; Ghalehno, M. D.; Shojaiishad, M.; Sharifpoor, H.; Taftiyan, M. H. Properties of three - layer particleboard made from wood of Athel (Tamarix aphylla) and pruning particles of almond (Amygdalus communis) and pistachio (Pistacia vera). Journal of Basic and Applied Scientific Research, v.1, n.8, p. 837-843, 2011. https://www.textroad.com/pdf/JBASR/J.\%20Basic.\%20Appl.\%20 Sci.\%20Res.,\%201(8)837-843,\%202011.pdf. 02 Aug. 2020.

Pommer, C. V.; Barbosa, W.; Tombolato, A. F. C. Pistache: possibilidade de cultivo no Brasil e tecnologia de produção. 2006. Hypertext Article. http://www.infobibos.com/Artigos/pistache/index.htm. 19 Jul. 2020.

Santiago, S. B.; Gonçalves, F. G.; Lelis, R. C. C.; Segundinho, P. G. A.; Paes, J. B.; Arantes, M. D. C. Colagem de madeira de eucalipto com adesivos naturais. Revista Matéria, v. 23, n. 3, e12151, 2018. https://doi.org/10.1590/S1517-707620180003.0485.

Sweet, M. S.; Winandy, J. E. Influence of Degree of Polymerization of Cellulose and Hemicellulose on Strength Loss in Fire - Retardant - Treated Southern Pine. Holzforschung, v. 53, n. 3, p. 311-317, 1999. https://doi.org/10.1515/HF.1999.051.

Teodoro, R.; Raabe, J.; Silva, D. W.; Mendes, R. F.; Mendes, L. M.; DenzinTonoli, G. H. Functionally graded MDP panels using bamboo particles. Key Engineering Materials, v. 668, p. 39-47, 2015. https://doi.org/10.4028/www.scientific.net/KEM.668.39. 